\title{
Continuous measurements of atmospheric oxygen and carbon dioxide on a North Sea gas platform
}

\author{
I. T. van der Laan-Luijkx, R. E. M. Neubert, S. van der Laan, and H. A. J. Meijer \\ Centre for Isotope Research (CIO), University of Groningen, Groningen, The Netherlands \\ Received: 17 July 2009 - Published in Atmos. Meas. Tech. Discuss.: 28 July 2009 \\ Revised: 11 January 2010 - Accepted: 11 January 2010 - Published: 28 January 2010
}

\begin{abstract}
A new atmospheric measurement station has been established on the North Sea oil and gas production platform F3, $200 \mathrm{~km}$ north off the Dutch coast $\left(54^{\circ} 51^{\prime} \mathrm{N}, 4^{\circ} 44^{\prime} \mathrm{E}\right)$. Atmospheric concentrations of $\mathrm{O}_{2}$ and $\mathrm{CO}_{2}$ are continuously measured using fuel cell technology and compact infrared absorption instruments, respectively. Furthermore, the station includes an automated air flask sampler for laboratory analysis of the atmospheric concentrations of $\mathrm{CO}_{2}, \mathrm{CH}_{4}$, $\mathrm{CO}$ and $\mathrm{O}_{2}$ and isotope measurements of $\delta^{13} \mathrm{C}, \delta^{18} \mathrm{O}$ and ${ }^{14} \mathrm{C}$ from $\mathrm{CO}_{2}$. This station is the first fixed sea based station with on-site continuous $\mathrm{O}_{2}$ and $\mathrm{CO}_{2}$ measurements and therefore yields valuable information about the $\mathrm{CO}_{2}$ uptake in coastal marine regions, specifically the North Sea. This paper presents the measurement station and the used methodologies in detail. In comparison to land-based stations, the data show low day-to-day variability, as they are practically free of nightly inversions as well as human influences, due to the station's remoteness. Therefore, the data set collected at this measurement station serves directly as background data for the coastal northwest European region. Additionally, the first data are presented showing the seasonal cycle as expected during August 2008 through June 2009. Furthermore, some short-term $\mathrm{O}_{2}$ and $\mathrm{CO}_{2}$ signals are presented. The observations at the platform include several large and fast changing negative atmospheric $\mathrm{O}_{2}$ excursions without an accompanying change in the $\mathrm{CO}_{2}$ signal, which most likely indicate marine $\mathrm{O}_{2}$ uptake.
\end{abstract}

\section{Correspondence to: \\ I. T. van der Laan-Luijkx \\ (i.t.luijkx@ rug.nl)}

\section{Introduction}

Highly precise and accurate atmospheric $\mathrm{O}_{2}$ measurements offer a significant contribution to our understanding of the global carbon cycle (Bender et al., 1996; Keeling et al., 1993; Keeling and Shertz, 1992). Specifically, combined measurements of atmospheric $\mathrm{O}_{2}$ and $\mathrm{CO}_{2}$ can be used to partition land and ocean $\mathrm{CO}_{2}$ uptake (Keeling et al., 1996; Langenfelds et al., 1999). The difference in behaviour of $\mathrm{O}_{2}$ and $\mathrm{CO}_{2}$ in ocean-atmosphere exchange yields valuable information about the global carbon cycle in general and the ocean $\mathrm{CO}_{2}$ uptake in particular, which cannot be acquired from measurements of $\mathrm{CO}_{2}$ concentrations alone.

Measuring atmospheric $\mathrm{O}_{2}$ concentrations is not a straightforward exercise. The absolute variations of $\mathrm{O}_{2}$ are in the same order of magnitude as for $\mathrm{CO}_{2}$, but they are to be detected against a much higher background. The atmospheric $\mathrm{O}_{2}$ concentration is about $209392 \mathrm{ppm}$ (Tohjima et al., 2005), compared to around $380 \mathrm{ppm}$ for $\mathrm{CO}_{2}$ (Forster et al., 2007). The first technique to measure atmospheric $\mathrm{O}_{2}$ with the required precision was based on interferometry and was developed by Keeling (1988a, b). Several other methods to measure atmospheric $\mathrm{O}_{2}$ have been designed during the past decades, including mass spectrometry (Bender et al., 1994), a paramagnetic analyzer (Manning et al., 1999), vacuum ultraviolet absorption (Stephens, 1999), gas chromatography (Tohjima, 2000) and a technique using fuel cells (Patecki and Manning, 2007; Stephens et al., 2007; Thompson et al., 2007).

Systematic measurements of atmospheric $\mathrm{O}_{2}$ have begun in 1989 by means of flask sampling at three sites (Keeling and Shertz, 1992). Since then, the flask-sampling network for atmospheric $\mathrm{O}_{2}$ measurements has been extended over the globe (Bender et al., 2005; Manning and Keeling, 2006; Tohjima et al., 2008) and later on also included continuous

Published by Copernicus Publications on behalf of the European Geosciences Union. 
on-site measurements (Kozlova et al., 2008; Manning, 2001; Popa et al., 2009; Thompson et al., 2009; Valentino et al., 2008).

In order to extend the existing data sets of atmospheric $\mathrm{O}_{2}$ and $\mathrm{CO}_{2}$, we have established a new atmospheric measurement station on the North Sea oil and gas production platform F3, $200 \mathrm{~km}$ north off the Dutch coast $\left(54^{\circ} 51^{\prime} \mathrm{N}\right.$, $\left.4^{\circ} 44^{\prime} \mathrm{E}\right)$. The measurement station includes instruments that continuously measure atmospheric $\mathrm{O}_{2}$ and $\mathrm{CO}_{2}$ concentrations on-site using the aforementioned fuel cell technique and infrared absorption, respectively. The location of the station is favourable since local effects - except for sea-atmosphere exchange - are practically absent. Furthermore, atmospheric inversions (causing large variability at land based stations) practically do not occur at sea, resulting in stable and calm $\mathrm{O}_{2}$ and $\mathrm{CO}_{2}$ signals. It is therefore an ideal location for measuring atmospheric background concentrations and studying air-sea interaction of $\mathrm{CO}_{2}$ and partitioning of $\mathrm{CO}_{2}$ emissions between the land biosphere and oceans. This station is the first fixed sea based station with on-site continuous $\mathrm{O}_{2}$ and $\mathrm{CO}_{2}$ measurements and will yield valuable information about the $\mathrm{CO}_{2}$ uptake in coastal marine regions, specifically about the North Sea. The data from this measurement station will be a valuable contribution to the existing European data sets of atmospheric $\mathrm{O}_{2}$ and $\mathrm{CO}_{2}$, since only few atmospheric measurements stations exist that are equipped to measure atmospheric $\mathrm{O}_{2}$ continuously.

The fuel-cell based atmospheric $\mathrm{O}_{2}$ analyzer is commercially available (Oxzilla II, Sable Systems). However, in order to measure atmospheric $\mathrm{O}_{2}$ at the required precision in the range of $1: 10^{6}$ (WMO, 2009) with this instrument, substantial re-design is necessary. The setup design comprises extensive gas handling techniques, including sample drying and pressure and temperature stabilization. Besides that, measurements are performed differentially, which implies continuous comparison to a known reference gas standard. Moreover, the setup is calibrated on a daily basis with a suite of two known calibration gases. This paper firstly describes the instrumental setup and analysis methods, subsequently the measurement site and finally the obtained initial results, including the first three quarters of a year of atmospheric $\mathrm{O}_{2}$ and $\mathrm{CO}_{2}$ data.

\section{Method and site description}

\section{$2.1 \mathrm{O}_{2}$ and $\mathrm{CO}_{2}$ analyzers}

Both the $\mathrm{O}_{2}$ and the $\mathrm{CO}_{2}$ analyzers are commercially available instruments. For $\mathrm{O}_{2}$ measurements we use the Oxzilla II instrument, available from Sable Systems, which was also used in a similar way by e.g. Stephens et al. (2007), Thompson et al. (2007) and Patecki and Manning (2007). The $\mathrm{CO}_{2}$ measurements are performed using two CarboCaps GMP343 from Vaisala. These compact and inexpensive $\mathrm{CO}_{2}$ analyzers have not been used before for atmospheric measurements concurrently with $\mathrm{O}_{2}$.

The operational principle of the Oxzilla $\mathrm{O}_{2}$ analyzer is based on fuel cell technology. These fuel cells (MAX250(B), Maxtec Inc.) consist of a lead anode, a gold cathode and weak acid serving as an electrolyte. The $\mathrm{O}_{2}$ from the incoming air stream initiates a net reaction in the fuel cells as given in Eq. (1).

$\mathrm{O}_{2}+2 \mathrm{~Pb}+4 \mathrm{H}^{+} \rightarrow 2 \mathrm{H}_{2} \mathrm{O}+2 \mathrm{~Pb}^{2+}$

This reaction generates a current, which is linearly proportional to the partial pressure of the $\mathrm{O}_{2}$ in the sampled air. The partial pressure of $\mathrm{O}_{2}$ also depends on the total pressure of the measured air. This requires a linear correction of the measured output signal to standard barometric pressure of 1013 mbar using the measured pressure $P$, measured by an accurate pressure sensor, as shown in Eq. (2).

$\mathrm{O}_{2}$ corrected $=\mathrm{O}_{2}$ measured $\cdot \frac{1013}{P}$

The fuel cells are temperature sensitive, therefore the Oxzilla is provided with an internal temperature compensation circuit. The Oxzilla is a differential analyzer, which continuously measures the difference between a reference gas and the sample air using two fuel cells.

The Vaisala CarboCap GMP343, a non-dispersive infrared analyzer, is used for measuring the $\mathrm{CO}_{2}$ concentration in the sample air by measuring a specific range of infrared absorption lines of $\mathrm{CO}_{2}$ in the sample air and comparing this to the absorption in a close-by frequency range without $\mathrm{CO}_{2} \mathrm{ab}$ sorption. Our setup includes two $\mathrm{CO}_{2}$ analyzers, each placed in series with one of the fuel cells. The $\mathrm{CO}_{2}$ analyzers are built into the housing of the $\mathrm{O}_{2}$ analyzer to ensure similar temperature stability for both $\mathrm{O}_{2}$ and $\mathrm{CO}_{2}$ measurements.

\subsection{Gas handling}

Due to the required precisions in atmospheric $\mathrm{O}_{2}$ and $\mathrm{CO}_{2}$ concentrations, the air streams that are to be analyzed by the aforementioned analyzers require careful gas handling. This includes several aspects, such as air-drying and pressure stabilization. The details of the gas handling are described in this section and are shown schematically in Fig. 1.

The sample air enters the system at the air inlet, consisting of a funnel and a filter $(5 \mu \mathrm{m})$. Subsequently, the sample air is pre-dried by a Nafion membrane column (Perma Pure, MD $11072 \mathrm{~S}$ ). The Nafion pre-drier uses a counter-flow of dry air to remove about $60 \%$ of the water content from the sample air. The outer side of the column is supplied with dry air from the outlet air stream from the automated flask sampler (see Sect. 2.5). The risk of influencing the sample air 


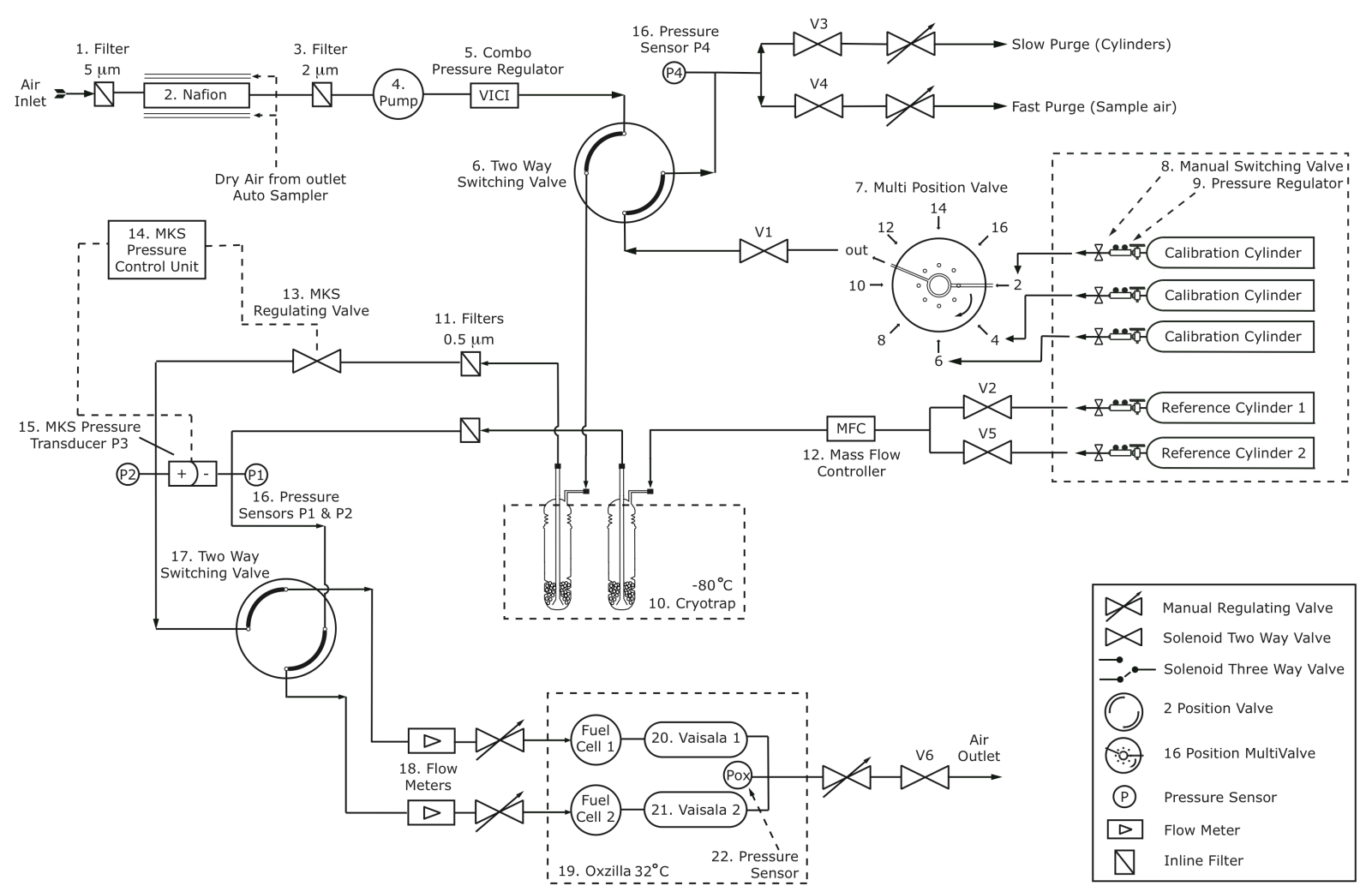

Fig. 1. Schematic of the measurement setup for continuous on-site $\mathrm{O}_{2}$ and $\mathrm{CO}_{2}$ measurements. The included gas handling techniques are shown: sample drying (see also Fig. 2) and pressure and temperature stabilization.

is therefore negligible, since the dry air on the outer side is the dried air stream that has been sampled just a few minutes earlier and has therefore an almost identical composition, see also Neubert et al. (2004).

The sample air is pumped through the system at a flow rate of around $40 \mathrm{ml} / \mathrm{min}$ using a diaphragm pump (KNF, $\mathrm{N}-86$, of which the wetted materials are PTFE and aluminium). A combo pressure regulator (VICI, PR50A30Z2) was used to smooth out pressure fluctuations introduced by the pump. A Valco 4-port, 2-way valve (ET44UWE) is used to select between the sample air and a set of calibration gases, which are selected by a 16-port multiposition valve (Valco, EMT2SD16MWE). Two 2-way solenoid valves (Parker Skinner, 71215SN1MF00N0C111C2) select which cylinder is used as the reference gas, using the second reference cylinder during the times that the first needs replacing. The flow rate of the selected reference gas is stabilized by a mass flow controller (Bronkhorst, F-201C-FAC-22-V) to around $40 \mathrm{ml} / \mathrm{min}$, equal to the flow of the sample gas. The flow rate is lower than in previously mentioned similar setups, in order to extend the lifetime of the reference cylinders, which is preferable at this remote location. All reference and calibration cylinders are filled at our laboratory using a RIX SA-3 compressor modified for atmospheric measurements (without adding CO and oil) (Mak and Bren- ninkmeijer, 1994). The cylinders are kept horizontally in order to increase the long-term stability of the gas standards (Keeling et al., 2007).

Thereafter the system consists of two parallel lines. Water vapour is removed from both air streams by the drying system, shown in Fig. 2. This system consists of two identical sides (A and B), which alternately dry the air streams. Each of these two sides consists of a cryo-cooler (Neslab CC$100)$ and glass traps partly filled with glass beads, placed in a Dewar filled with a thermo fluid (SilOil) and each Dewar includes a heating coil. By using two identical sides, the water from one of the cryo-traps (side B in Fig. 2) can be removed while the other (side A in Fig. 2) is drying the air streams at a temperature of around $-80^{\circ} \mathrm{C}$. The water is removed from the traps by back-flushing with air while the temperature of the thermo fluid is around $+40^{\circ} \mathrm{C}$. This drying system does therefore not need servicing in the form of replacing cryotraps and can run unattended during long periods of time. More details are given by Neubert et al. (2004).

Since both $\mathrm{O}_{2}$ and $\mathrm{CO}_{2}$ are measured differentially, the pressure difference between both lines has to be kept very stable. For that reason the pressure in both lines is equalized - after drying the air streams - using a 1 mbar fullscale pressure transducer (MKS, 223B), a regulating valve (MKS, 248A) and a pressure control unit (MKS, 250E). The 


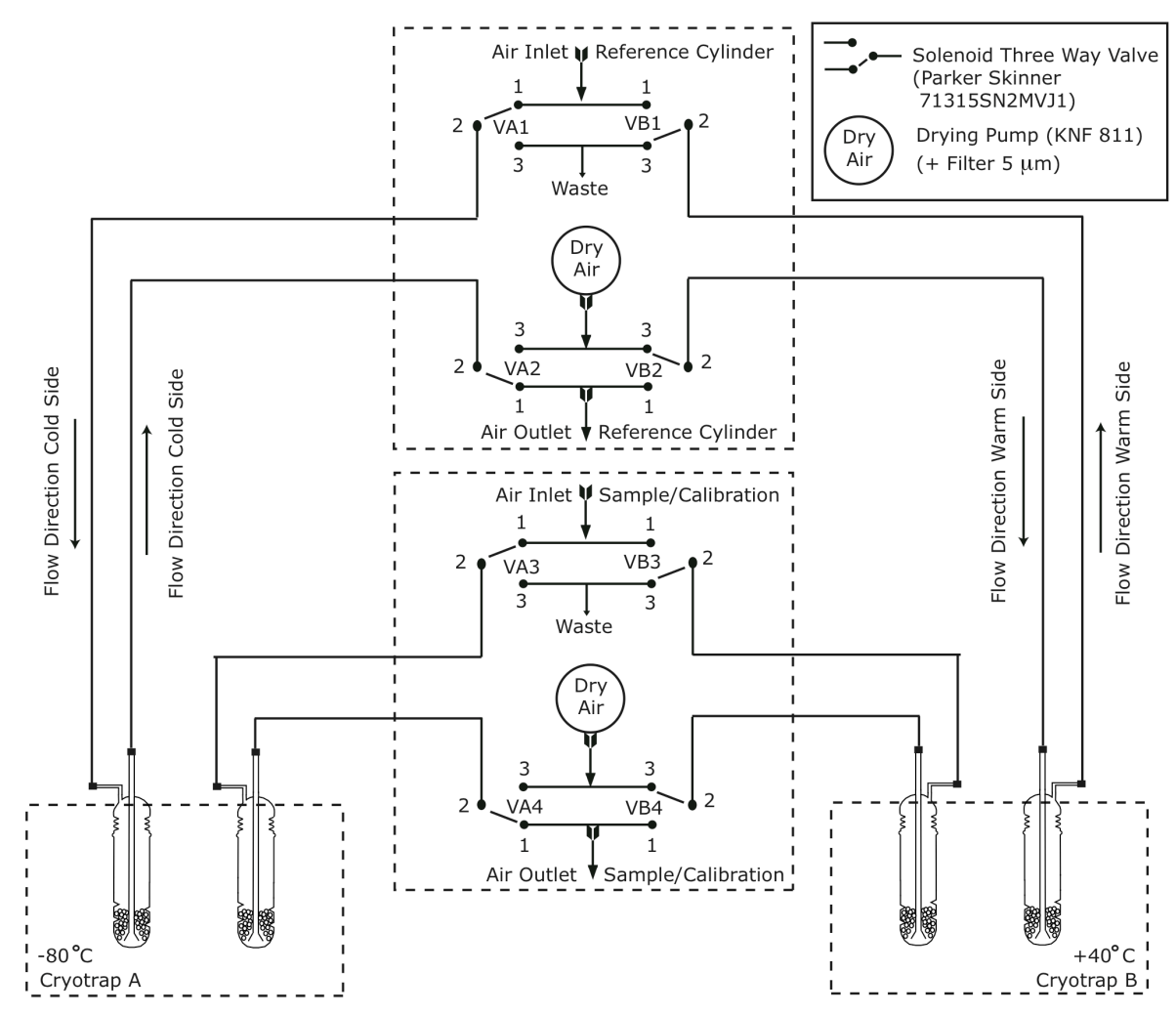

Fig. 2. Schematic of the automated air-drying setup. Cryo-trap A and B are alternately cold $\left(-80^{\circ} \mathrm{C}\right)$ or warm $\left(+40^{\circ} \mathrm{C}\right)$ in order to, respectively freeze out water from the sample air or to clear the traps of ice.

regulating valve equalizes the pressure in the sample (or calibration) line to the reference line with a stated precision of $0.3 \%$ of the full-scale. A second Valco 4-port, 2-way valve is used to switch the air streams between both fuel cells and $\mathrm{CO}_{2}$ analyzers in order to increase the measurement precision of both instruments and to eliminate the specific differences of each fuel cell or CarboCap by alternating which cell acts as the reference cell and which cell acts as the sample cell at regular time intervals of $5 \mathrm{~min}$ (Stephens et al., 2007). Our switch time between both fuel cells and CarboCaps is significantly larger than the aforementioned reference as well as other similar designs (Patecki and Manning, 2007; Thompson et al., 2007), due to the large internal volume of the CarboCaps (around $60 \mathrm{ml}$ ) and lower flow rate. The time to complete the flushing of the CarboCaps is longer than for the fuel cells. Since the fuel cells and the CarboCaps are switched regularly using the same Valco valve, the time required for flushing CarboCaps was the limiting factor and the switching time was therefore chosen to be every $5 \mathrm{~min}$.

Remaining parts of the setup, which do not require extensive explanation, include filters, tubing $\left(1 / 8^{\prime \prime}\right.$ and some $1 / 16^{\prime \prime}$ stainless steel (Swagelok) and 1/4" Synflex 1300 tubing) and fittings (Swagelok), 2-way valves (Swagelok, SS-41S2), Solenoid 2-way valves (Parker Skinner, 71215SN1MF00N0C111C2), pressure and flow sensors for remote monitoring of the system (resp. SunX, DPH/A07 and $\mathrm{AE}$ sensors 50S-5). We avoided the use of T-junctions in the setup to avoid fractionation of the measured air (Manning, 2001).

Valve actuation, pump operation and signal recording of $\mathrm{O}_{2}, \mathrm{CO}_{2}$ and additional parameters like pressure and flow were done by software programmed in Pascal (Delphi). This software furthermore automated the sequencing of the calibration procedure (see Sect. 2.3) and the data transfer by email.

\section{3 $\mathrm{O}_{2}$ and $\mathrm{CO}_{2}$ calculations and calibration}

To increase the measurement precision of the $\mathrm{O}_{2}$ and $\mathrm{CO}_{2}$ measurements, reference and sample are switched between the fuel cells and CarboCaps at regular time intervals of 5 min. For $\mathrm{O}_{2}$, this yields a double differential $\mathrm{O}_{2}$ signal, which is defined by Eq. (3) (Thompson et al., 2007).

$\Delta(\Delta)=\left(S_{1}-R_{2}\right)-\left(R_{1}-S_{2}\right)$

$S$ and $R$ are the $\mathrm{O}_{2}$ concentrations of the Sample and the Reference gases in $\% \mathrm{O}_{2}$ (of the total measured air) and the subscripts indicate the respective fuel cells on which they were measured. The $\Delta(\Delta)$ symbol indicates that this is a double differential signal. Each measurement period of 5 min consists of approximately 500 data points (the output interval of the Oxzilla is set to $0.6 \mathrm{~s}$ ). The values for $S$ and $R$ are 
determined using the average of the final 200 data points before the next switch of the gases between the fuel cells. The optimal amount of data points was obtained by studying the minimum error in the mean of a 5 min period while varying the amount of data points included in the calculation of the average and accompanying error (similar to the Allen variance procedure). This method gives the maximum amount of data points to be included in the calculation of the average, while excluding the data points that are influenced by either remains of the other gas before the switch or drifts of the instrument. The $\mathrm{O}_{2} \Delta(\Delta)(\%)$ is the change in the differentially measured $\mathrm{O}_{2}$ signal and is proportional to the difference between the concentrations of the sample and the reference gas.

The raw $\mathrm{O}_{2} \Delta(\Delta)$ values are given as $\mathrm{O}_{2}$ partial pressure and expressed in $\% \mathrm{O}_{2}$. These values are obtained directly from the Oxzilla instrument. As fluctuations in the concentrations of other atmospheric gases, such as $\mathrm{CO}_{2}$, influence the $\mathrm{O}_{2}$ partial pressure, the $\mathrm{O}_{2}$ measurements are expressed as a ratio to the $\mathrm{N}_{2}$ concentration, which is insensitive to these changes in other gases. Internationally, the common way to report $\mathrm{O}_{2}$ concentrations is therefore to use the $\delta\left(\mathrm{O}_{2} / \mathrm{N}_{2}\right)$ value (per meg). This is the ratio between the $\mathrm{O}_{2} / \mathrm{N}_{2}$ ratio of the measured concentrations and the $\mathrm{O}_{2} / \mathrm{N}_{2}$ ratio of a known reference gas, as given in Eq. (4) (Keeling and Shertz, 1992).

$\delta\left(\mathrm{O}_{2} / \mathrm{N}_{2}\right)=\left(\frac{\left(\mathrm{O}_{2} / \mathrm{N}_{2}\right)_{\text {sample }}}{\left(\mathrm{O}_{2} / \mathrm{N}_{2}\right)_{\text {reference }}}-1\right)$

For natural air, $\delta\left(\mathrm{O}_{2} / \mathrm{N}_{2}\right)$ is a very small number, and is therefore usually expressed in per meg, which is obtained by multiplying Eq. (4) by $10^{6}$. The relationship between the concentration in $\mathrm{ppm}(\mu \mathrm{mol} / \mathrm{mol})$ and per meg for atmospheric oxygen is calculated by using Eq. (5) (Kozlova et al., 2008) and the standard mole fraction of oxygen in air, which is defined as: $\mathrm{S}_{\mathrm{O}_{2}}=0.20946$ (Machta and Hughes, 1970).

$$
1 \mathrm{ppm}=\frac{1}{\left(1-\mathrm{S}_{\mathrm{O}_{2}}\right) \cdot \mathrm{S}_{\mathrm{O}_{2}}} \approx 6.04 \text { per meg }
$$

The measured $\mathrm{O}_{2} \Delta(\Delta)$ value (in \%) is first converted to the apparent mole fraction $\left(\delta \mathrm{XO}_{2}\right)$ using the calibration procedure as described below and secondly to $\delta\left(\mathrm{O}_{2} / \mathrm{N}_{2}\right)$ by correcting for the dilution by the amount of $\mathrm{CO}_{2}$ in the sampled air using Eq. (6) as described in Kozlova et al. (2008). Corrections for other atmospheric species, such as Argon, are not included since their variations in natural air are negligible.

$\delta\left(\mathrm{O}_{2} / \mathrm{N}_{2}\right)_{\text {sample }}=\frac{\delta \mathrm{XO}_{2}+\left(\Delta \mathrm{CO}_{2} \cdot \mathrm{S}_{\mathrm{O}_{2}}\right)}{\left(1-\mathrm{S}_{\mathrm{O}_{2}}\right) \cdot \mathrm{S}_{\mathrm{O}_{2}}}$ (in per meg)

where $\mathrm{S}_{\mathrm{O}_{2}}=0.20946$ and $\Delta \mathrm{CO}_{2}=\left[\mathrm{CO}_{2}\right]_{\text {sample }}-363.29(\mathrm{ppm})$, which is the $\mathrm{CO}_{2}$ concentration of the sample gas minus that of an arbitrarily defined standard atmospheric composition. $\delta \mathrm{XO}_{2}$ is the difference between the relative $\mathrm{O}_{2}$ apparent mole fraction of the sample and the reference air, which is obtained by calibration of the $\Delta(\Delta)$ signal.
For this calibration we use 2 gases, which are measured on a 23-h basis, with respect to the same reference gas as the sample measurements. The sample $\delta \mathrm{XO}_{2}$ values are calibrated using a linear interpolation between the measurements of the two calibration gases. The measurements of the two calibration gases are used to construct the linear calibration line which is used to convert the measured $\Delta(\Delta)$ signal of the sample to $\delta \mathrm{XO}_{2}$ values. For this, the measured $\delta \mathrm{O}_{2} / \mathrm{N}_{2}$ values of the calibration gases are converted to apparent mole fractions, using their measured $\mathrm{CO}_{2}$ concentration and the same Eq. (6). As the scatter in individual measurements is larger than the drift over several weeks (see Sects. 3.1 and 3.2 ), the best calibration is obtained by constructing one average linear calibration line for each reference gas period (consisting of several weeks). Each $23 \mathrm{~h}$, both calibration cylinders are measured for $1 \mathrm{~h}$ and $15 \mathrm{~min}$. The average of the last 3 switching cycles, i.e. $15 \mathrm{~min}$, is used for determining the linear calibration line. The amount of data that is used is relatively small, due to the long flushing time of the drying system. As can be seen in Figs. 1 and 2, switching between different gases (sample air, calibration gases, target gas) implies flushing the glass traps in the drying system, which at the used flow rate takes about $1 \mathrm{~h}$ to complete. Although the calibration gases are dried air, we have chosen the location of the drying system as shown in Fig. 1 in order to ensure identical gas handling for both sample air and calibration and target gases.

The obtained $\delta\left(\mathrm{O}_{2} / \mathrm{N}_{2}\right)$ values are relative values on a predefined scale. In this paper all $\delta\left(\mathrm{O}_{2} / \mathrm{N}_{2}\right)$ values are expressed relatively to our Groningen Centre for Isotope Research (CIO) scale, which is defined by air cylinder " 2534 " and maintained by a suite of reference cylinders. More information about this scale is presented in Sirignano et al. (2008). Thanks to a newly-purchased suite of primary reference cylinders, filled and calibrated by Keeling, SIOUCSD, La Jolla and an intercomparison programme within CarboEurope IP, our internal scale will be tied to that of other locally maintained scales soon.

A similar differential approach is used for the calculations of the concentration of $\mathrm{CO}_{2}$, since the air streams are also switched between the CarboCaps with intervals of $5 \mathrm{~min}$. For $\mathrm{CO}_{2}$ the $\Delta(\Delta)$ value is the change in the differentially measured $\mathrm{CO}_{2}$ signal and is directly proportional to the difference between the sample and the reference gas concentrations. Each measurement period of $5 \mathrm{~min}$ consists of approximately 150 data points (the output interval of the CarboCaps is set to $2 \mathrm{~s}$ ). The values for $S$ and $R$ (see Eq. 3) are the concentrations of $\mathrm{CO}_{2}$ of the Sample and the Reference gases (the direct output of the CarboCaps, given in uncalibrated ppms) and are determined using the average of the final 80 data points before the next switch of the gases between the CarboCaps. The optimal amount of data points was obtained similarly to that of the $\mathrm{O}_{2}$ measurements. Another way to determine the values for $S$ and $R$ is by fitting the data of each switching cycle with an exponential function. This 
method, however, proved to be more vulnerable to errors, especially in cases where the difference between the values for $S$ and $R$ is small. Therefore the average of the last part of the measurements was used. As for $\mathrm{O}_{2}$ calculations, linear calibration provides a conversion from the $\Delta(\Delta)$ value to the $\mathrm{CO}_{2}$ concentration of the sample gases.

The $\delta \mathrm{O}_{2} / \mathrm{N}_{2}$ values and the $\mathrm{CO}_{2}$ concentrations for the calibration gases are determined in the CIO laboratory using, respectively Dual Inlet Isotope Ratio Mass Spectrometry (IRMS, MicroMass Optima) and Gas Chromatography (Hewlett-Packard model 6890). Additional information is provided in Sirignano et al. (2008).

\subsection{Measurement site description}

The F3-FB-1 (short: F3) platform produces both oil and gas. Until 2008 it was owned by the Dutch oil company NAM (Nederlandse Aardolie Maatschappij) and after that it was transferred to Gaz de France (GdF) Suez. It is situated $200 \mathrm{~km}$ north of the Dutch coast $\left(54^{\circ} 51^{\prime} \mathrm{N}, 4^{\circ} 44^{\prime} \mathrm{E}\right)$, see Fig. 3. The main local source of $\mathrm{CO}_{2}$ is the gas power plant on the platform itself. Besides that there are occasional helicopters, supply ships and tankers, a diesel engine for the operation of cranes and a small permanent gas flare for safety purposes. The total average $\mathrm{CO}_{2}$ production at the platform is about 100 tonnes of $\mathrm{CO}_{2}$ per day, which is 5 times smaller than the daily $\mathrm{CO}_{2}$ production of a typical LNG carrier (BP, 2007).

The platform consists of two parts connected by a bridge of $60 \mathrm{~m}$. One part is the production platform, the other is the accommodation platform. The positioning of the production platform - where the main $\mathrm{CO}_{2}$ sources are - was intentionally north of the accommodation platform, for safety purposes. As the prevailing wind direction is south-west, potential leakages or fires are blown away from the accommodation platform, as is the exhaust from the power plant and the gas flare. The ideal situation for atmospheric measurements on this oil and gas platform is therefore on the southwest corner of the accommodation platform. This is where the air-inlet of our measurement system as described in the previous sections is situated. In case of northern wind an influence might be expected from local $\mathrm{CO}_{2}$ production, however the air inlet is partly shielded by the accommodation platform itself. Other possible local influences on the measurements include the air-conditioning system at the accommodation platform and the constant seawater circulation for cooling purposes in the production process, resulting in artificial upwelling. The air-inlet is on the topmost deck, which is $46 \mathrm{~m}$ a.s.l. The North Sea depth at the platform is $44 \mathrm{~m}$. The distance from the power plant exhaust and the gas flare to the air-inlet of our measurement system is around 90 and $130 \mathrm{~m}$, respectively.

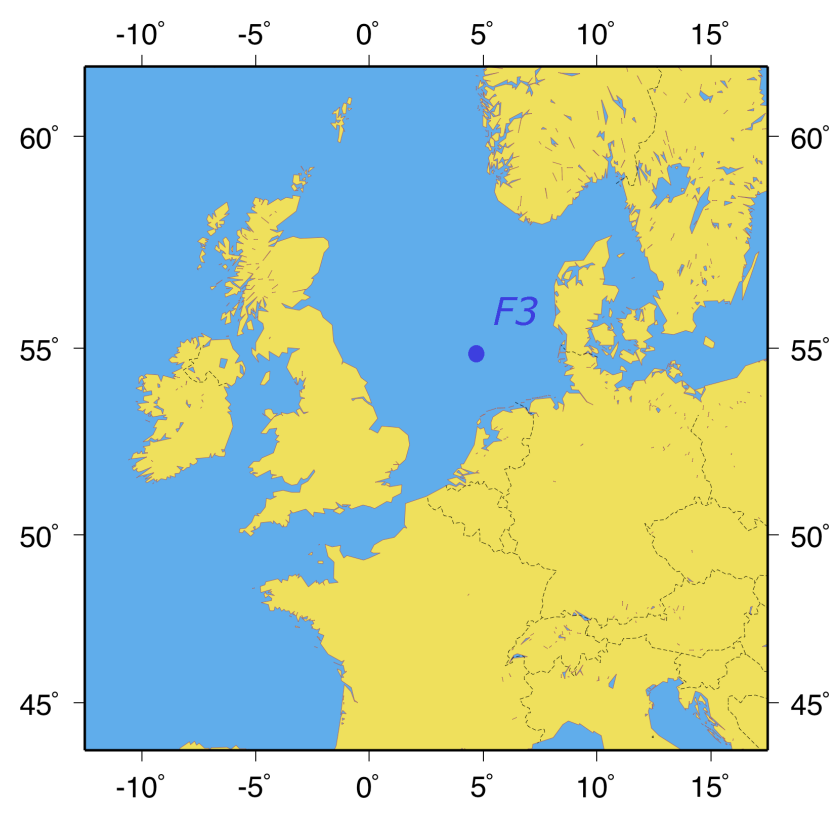

Fig. 3. Location of the atmospheric measurement station on oil and gas production platform $\mathrm{F} 3$.

As the location of the platform is remote, the measurement setup requires extensive automation. This is achieved largely by using internally developed software and internet access to the measurement computer. Remaining servicing like replacing reference cylinders is managed by the platform staff.

\subsection{Additional equipment}

Our measurement station is also equipped with an automatic air flask sampler (Neubert et al., 2004). This "AutoSampler" fills flasks with dried air, which are to be shipped back to the Centre for Isotope Research (CIO) laboratory for analysis. The analyses include measurements of the concentrations of $\mathrm{CO}_{2}$ and $\delta \mathrm{O}_{2} / \mathrm{N}_{2}$ for crosschecking of the continuous instrument. Furthermore other greenhouse and trace gas measurements, such as $\mathrm{CH}_{4}$ and $\mathrm{CO}$ concentrations, are performed, as well as measurements of the isotopic composition of $\mathrm{CO}_{2}$ $\left(\delta^{13} \mathrm{C}, \delta^{18} \mathrm{O}\right.$ and $\left.\Delta^{14} \mathrm{C}\right)$. $\mathrm{CO}$ concentrations and $\Delta^{14} \mathrm{C}$ are important indicators for contamination of the sample air with $\mathrm{CO}_{2}$ from local sources. Low $\Delta^{14} \mathrm{C}$ values indicate the influence of fossil fuel combustion. $\mathrm{CO}$ is a side product in fossil fuel combustion, and high $\mathrm{CO}$ values therefore also reveal local influences, see e.g. Gamnitzer et al. (2006).

Laboratory measurements of the flask samples are done using aforementioned Dual Inlet Isotope Ratio Mass Spectrometry (IRMS) (for $\delta \mathrm{O}_{2} / \mathrm{N}_{2}, \delta^{13} \mathrm{C}$ and $\delta^{18} \mathrm{O}$ ), gas chromatography (for $\mathrm{CO}_{2}, \mathrm{CH}_{4}$ and $\mathrm{CO}$ ) and Accelerator Mass Spectrometry (for $\Delta^{14} \mathrm{C}$ ). More information on the measurement techniques can be found in Sirignano et al. (2008) and van der Plicht et al. (2000). 


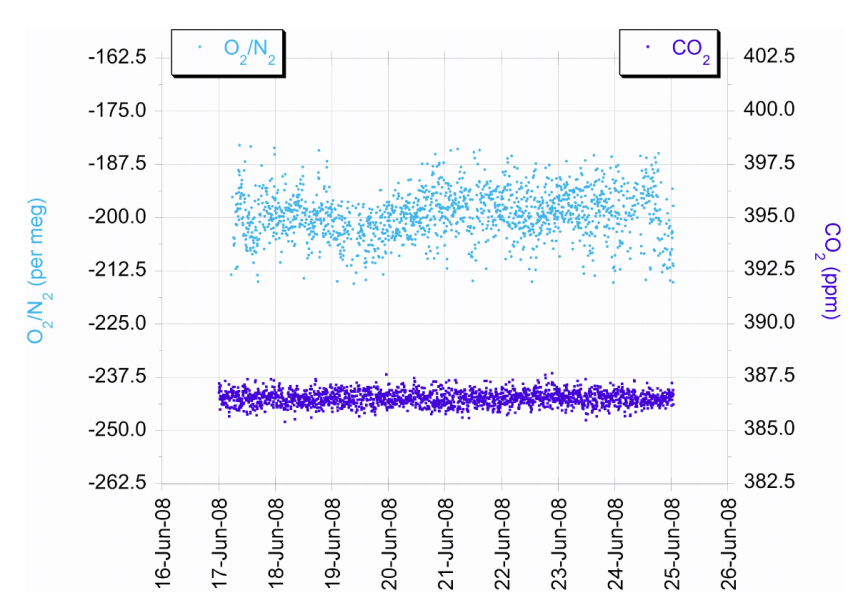

Fig. 4. Measurements of $\delta \mathrm{O}_{2} / \mathrm{N}_{2}$ (lighter circles) and for $\mathrm{CO}_{2}$ (darker squares) during a laboratory test run of the measurement system. Both $y$-axes have been adjusted so that their ranges are nearly the same on a molar basis.

The platform includes meteorological facilities as well, governed by the Royal Netherlands Meteorological Institute (KNMI). All required meteorological data (temperature, pressure, relative humidity, cloud cover, wind speed and wind direction) are measured continuously as well as parameters related to the sea surface, like mean tidal level and wave height.

\section{Results and discussion}

\subsection{Laboratory tests}

Before the installation on the platform the measurement system has been tested in the CIO laboratory. These tests were performed under laboratory-controlled "ideal" circumstances and the test setup did not include the air-drying system (Fig. 2), as the tests were performed using dry air cylinders. Figure 4 shows the results of a longer-term test. In this test two cylinders were constantly measured differentially during a period of 9 days. Both the $\delta \mathrm{O}_{2} / \mathrm{N}_{2}$ and the $\mathrm{CO}_{2}$ signal showed sufficient stability in this period. The long term ( 9 days) measurement precision ( $1 \sigma$ standard deviation) were 5 per meg and $0.3 \mathrm{ppm}$ for $\delta \mathrm{O}_{2} / \mathrm{N}_{2}$ and $\mathrm{CO}_{2}$, respectively. On the short term $(0.5 \mathrm{~h})$ the $1 \sigma$ standard deviations were 4 per meg and $0.28 \mathrm{ppm}$, respectively. Although the $\mathrm{CO}_{2}$ precision is lower than state-of-the-art, these results are satisfying, since we are mainly interested in the Atmospheric Potential Oxygen (APO) which is a combination of $\mathrm{O}_{2}$ and $\mathrm{CO}_{2}$ (see Sect. 3.3) and in the calculation of APO the $\mathrm{O}_{2}$ precision contributes the largest error. Furthermore, the CarboCap $\mathrm{CO}_{2}$ analyzers are relatively inexpensive and require practically no maintenance.

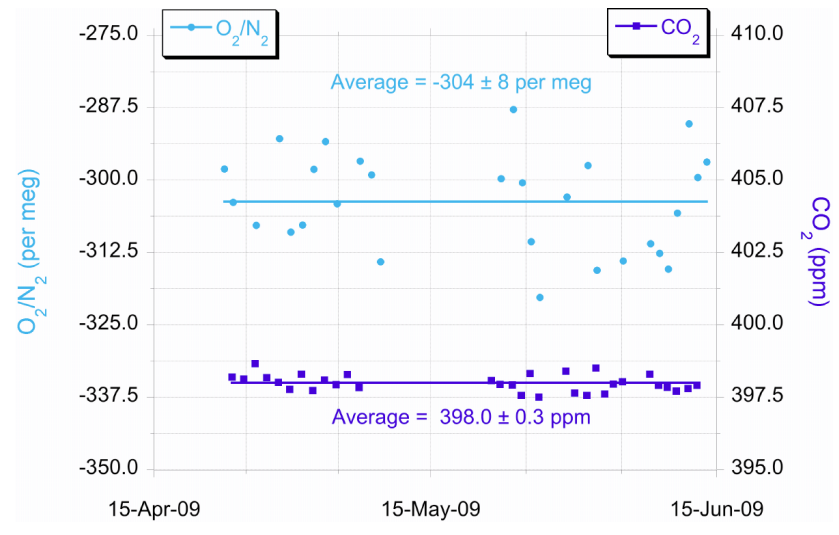

Fig. 5. Measurements of the target cylinder for $\delta \mathrm{O}_{2} / \mathrm{N}_{2}$ (lighter circles) and for $\mathrm{CO}_{2}$ (darker squares), measured during April through June 2009. Both $y$-axes have been adjusted so that their ranges are nearly the same on a molar basis.

\subsection{Target measurements}

Besides the calibration cylinders, which are measured every $23 \mathrm{~h}$, the measurement sequence also includes the measurement of a target cylinder. This cylinder is also measured every $23 \mathrm{~h}$ for $1 \mathrm{~h}$ and $15 \mathrm{~min}$. The measurements of the target cylinder are treated as if they were air samples, in order to obtain a reliable indicator for precision and (long-term) measurement accuracy for the system. Each target measurement period yields a result, which is the average of the three last 5 min measurement periods. Figure 5 shows the results of the measurements of the target cylinder during spring 2009 for both $\delta \mathrm{O}_{2} / \mathrm{N}_{2}$ and $\mathrm{CO}_{2}$. The averages of the target measurements of $\delta \mathrm{O}_{2} / \mathrm{N}_{2}$ and $\mathrm{CO}_{2}$ are indicated in the figure. Each data point is the average of three single measurements. The best estimate of the $1 \sigma$ standard deviation of our measurements is the average of the standard deviations of each set of three single measurements. We find 16 per meg for $\delta \mathrm{O}_{2} / \mathrm{N}_{2}$ and $0.2 \mathrm{ppm}$ for $\mathrm{CO}_{2}$, the result for $\delta \mathrm{O}_{2} / \mathrm{N}_{2}$ being rather disappointing. For the entire period shown in Fig. 5, the measurement precision of the target measurements, based on the spread of the 3-point averages around the long-term mean, was 8 per meg for $\delta \mathrm{O}_{2} / \mathrm{N}_{2}$ and $0.3 \mathrm{ppm}$ for $\mathrm{CO}_{2}$. For $\delta \mathrm{O}_{2} / \mathrm{N}_{2}$ this improvement is according to expectations, as the 3-point averages should be $\sqrt{ } 3$ times as precise as the $1 \sigma$ standard deviation of the single measurements. For $\mathrm{CO}_{2}$, the longterm instability and drifts apparently are becoming more significant. As the $\mathrm{CO}_{2}$ measurements are more accurate on a molar basis than for $\delta \mathrm{O}_{2} / \mathrm{N}_{2}$, the simultaneous improvement for $\delta \mathrm{O}_{2} / \mathrm{N}_{2}$ and worsening for $\mathrm{CO}_{2}$ are consistent nevertheless. Measurements of the target cylinder in other periods show similar results. The behaviour of the target cylinder shows more spread for $\delta \mathrm{O}_{2} / \mathrm{N}_{2}$ than expected based on the laboratory test results. We are currently working on improvements of the system, which are discussed in Sect. 4.1. 


\subsection{Atmospheric observations}

The continuous measurements for $\delta \mathrm{O}_{2} / \mathrm{N}_{2}$ and $\mathrm{CO}_{2}$ have been started at the end of August 2008. Flask samples have been collected on a weekly basis, generally during wellmixed atmospheric conditions and preferred wind direction, i.e. between south and west. Figure 6 shows the combined first data from the $\mathrm{F} 3$ platform for continuous and flask measurements between August 2008 and June 2009. Although the measurements do not yet cover an entire year, the amplitude of the seasonal cycle can be estimated. In this section only the peak-trough difference will be discussed, which we call the amplitude in the rest of the text. The seasonal amplitude for $\mathrm{CO}_{2}$ is about $16 \mathrm{ppm}$. For $\delta \mathrm{O}_{2} / \mathrm{N}_{2}$ a single harmonic fit of the data yields an amplitude of about 110 per meg. When looking at the data however, this is likely to be too small, and an estimate by the eye would produce about 150 per meg. For $\mathrm{CO}_{2}$ the seasonal amplitude compares well to the marine boundary layer reference from the same latitude from the GLOBALVIEW- $\mathrm{CO}_{2}$ (2008) database with an amplitude of $15 \mathrm{ppm}$. Both $\mathrm{O}_{2}$ and $\mathrm{CO}_{2}$ amplitudes can be compared to the observations at other stations at similar latitudes. For station Lutjewad $\left(53^{\circ} 24^{\prime} \mathrm{N}, 6^{\circ} 21^{\prime} \mathrm{E}\right)$ in the Netherlands the seasonal amplitude of $\mathrm{CO}_{2}$ is $14 \mathrm{ppm}$ as given in van der Laan et al. (2009). This value is based on continuous measurements. For both Lutjewad and Mace Head, Ireland $\left(53^{\circ} 20^{\prime} \mathrm{N}, 9^{\circ} 54^{\prime} \mathrm{W}\right)$, flask data have been presented by Sirignano et al. (2008), who show a seasonal amplitude of 153 and 102 per meg for $\delta \mathrm{O}_{2} / \mathrm{N}_{2}$ and 16 and $14 \mathrm{ppm}$ for $\mathrm{CO}_{2}$, respectively. The seasonal amplitudes of $\mathrm{CO}_{2}$ and $\mathrm{O}_{2}$ at other stations at comparable latitudes are: 135 per meg and $15.5 \mathrm{ppm}$ for Ochsenkopf, Germany $\left(50^{\circ} 01^{\prime} \mathrm{N}, 11^{\circ} 48^{\prime} \mathrm{E}\right)$ (Thompson et al., 2009), 163 per meg and 15.4 ppm for Shetland Islands, Scotland $\left(60^{\circ} 28^{\prime} \mathrm{N}, 1^{\circ} 28^{\prime} \mathrm{W}\right)$ and 134 per meg and $26.6 \mathrm{ppm}$ for ZOTTO, Siberia $\left(60^{\circ} 80^{\prime} \mathrm{N}, 89^{\circ} 35^{\prime} \mathrm{E}\right.$ ) (both from Kozlova et al., 2008). When comparing the F3 seasonal amplitudes to all 5 stations, $\mathrm{CO}_{2}$ does not show much variation and the $\mathrm{F} 3$ data is in the same range, while the $\mathrm{O}_{2}$ does vary considerably. Using the estimate of 150 per meg, the amplitude of the $\mathrm{O}_{2}$ seasonal cycle of the $\mathrm{F} 3$ platform compares best with that of Lutjewad and Shetland Islands, which is expected from the similar coastal marine nature of these sites (although Lutjewad definitely is subject to continental influences as well).

Although measurement precision for the continuous $\delta \mathrm{O}_{2} / \mathrm{N}_{2}$ measurements still should (and can) be improved substantially, the results in Fig. 6 clearly indicate the partial seasonal cycle as expected during autumn through spring. Moreover, the comparison between the continuous measurements and the flask samples shows a good agreement for both $\mathrm{CO}_{2}$ and $\delta \mathrm{O}_{2} / \mathrm{N}_{2}$. The $\delta \mathrm{O}_{2} / \mathrm{N}_{2}$ scale for the continuous measurement system is coupled to the scale of the IRMS in the CIO laboratory. Here we measure the flask samples as well as the calibration and reference gas cylinders for the continuous measurements, enabling a direct comparison of $\delta \mathrm{O}_{2} / \mathrm{N}_{2}$ measurements on an identical scale.

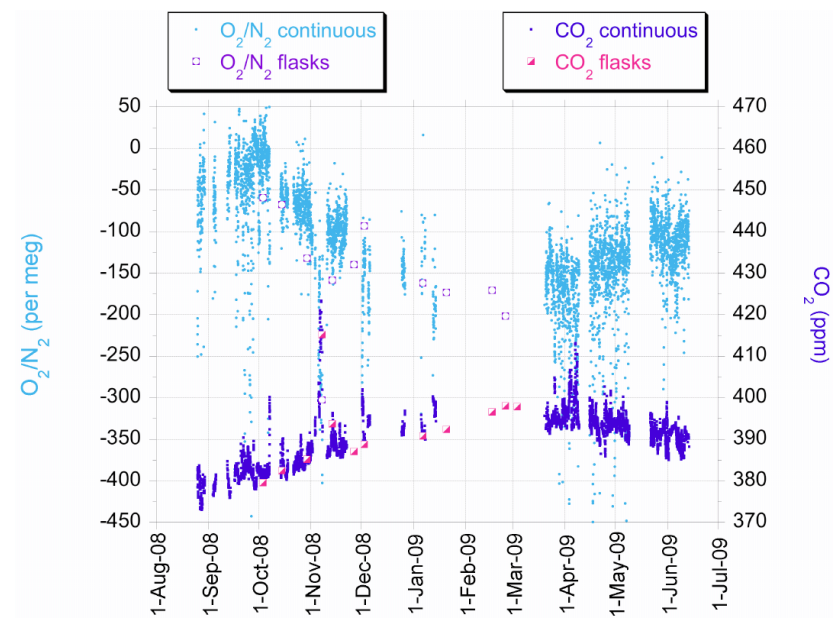

Fig. 6. Observations at the F3 platform for the period August 2008 through June 2009. The continuous measurements of $\delta \mathrm{O}_{2} / \mathrm{N}_{2}$ (small light circles) and $\mathrm{CO}_{2}$ (small dark squares) were performed with the Oxzilla/CarboCap setup as described in Sect. 2. The data points are half-hourly averages and include all measurements. Also shown are measurements of flask samples (open symbols). Both yaxes have been adjusted so that their ranges are nearly the same on a molar basis. Although the measurements do not yet cover an entire year, the amplitude of the seasonal cycle of $\delta \mathrm{O}_{2} / \mathrm{N}_{2}$ can be estimated. The seasonal amplitudes are about 150 per meg for $\delta \mathrm{O}_{2} / \mathrm{N}_{2}$ and $16 \mathrm{ppm}$ for $\mathrm{CO}_{2}$. This compares well to other observations.

Most noticeably when studying the results in Fig. 6, is that in contrast to land-based stations, the data from the platform do not show any diurnal cycles caused by a nightly inversion layer. In marine environments these inversions are practically absent, as is evident from the figure. Besides that, the station is located in a remote area, far away from major human influences and accompanying $\mathrm{O}_{2}$ and $\mathrm{CO}_{2}$ sources and sinks. Therefore, the data set collected at this measurement station serves directly as background data for the coastal northwest European region.

The continuous measurements show also local effects on smaller time scales. An example is shown in Fig. 7a, during a day in November 2008. These data show an inverse relationship between $\delta \mathrm{O}_{2} / \mathrm{N}_{2}$ and $\mathrm{CO}_{2}$. In Fig. 7b the relationship between $\delta \mathrm{O}_{2} / \mathrm{N}_{2}$ and $\mathrm{CO}_{2}$ is plotted, where the slope of the correlation represents the oxidative ratio (OR) between $\delta \mathrm{O}_{2} / \mathrm{N}_{2}$ and $\mathrm{CO}_{2}$. The linear fit $\left(R^{2}=0.61\right)$ yields an $\mathrm{OR}$ of $-1.31 \pm 0.09$ moles of $\mathrm{O}_{2}$ per mole of $\mathrm{CO}_{2}$, most likely representing local fossil fuel combustion (from e.g. a supply ship, tanker), changing air masses or a combination of both.

Another small-scale event series measured by the continuous measurement system is shown in Fig. 8. These results show very large $\delta \mathrm{O}_{2} / \mathrm{N}_{2}$ decreases during the afternoons on three consecutive days in September 2008. Similar events have occurred irregularly and infrequently after the first observation. No concurrent $\mathrm{CO}_{2}$ signal is observed during these periods. The days of this event shown in Fig. 8 

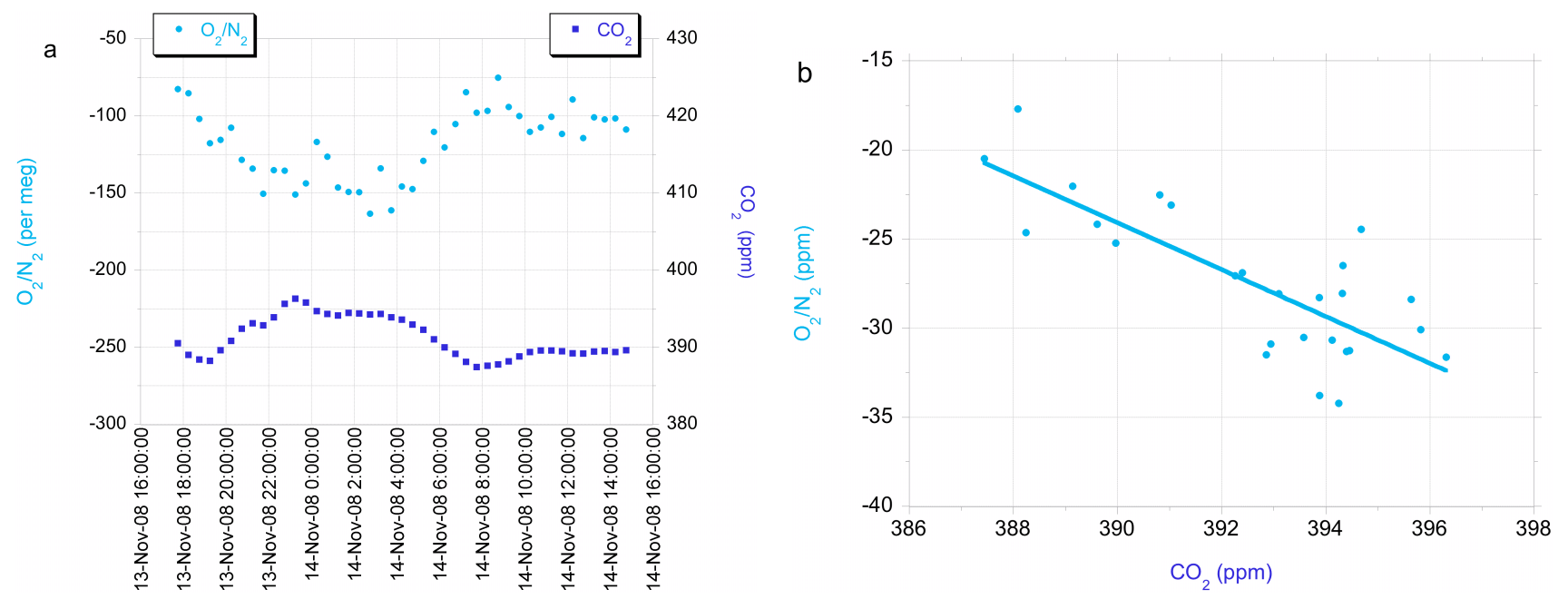

Fig. 7. Observations at the $\mathrm{F} 3$ platform for $\delta \mathrm{O}_{2} / \mathrm{N}_{2}$ (lighter circles) and $\mathrm{CO}_{2}$ (darker squares) on 13 and 14 November 2008 (a) and correlation between $\delta \mathrm{O}_{2} / \mathrm{N}_{2}$ and $\mathrm{CO}_{2}$ during the peak (b). The linear fit shown in (b) yields a slope of $-1.31 \pm 0.09\left(R^{2}=0.61\right)$.

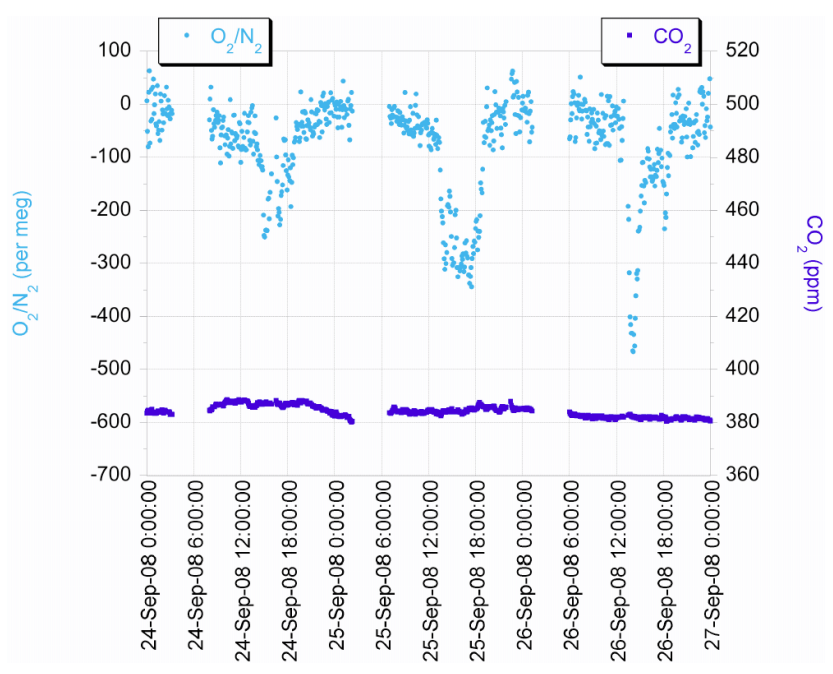

Fig. 8. Observations at the $\mathrm{F} 3$ platform for $\delta \mathrm{O}_{2} / \mathrm{N}_{2}$ (lighter circles) and $\mathrm{CO}_{2}$ (darker squares) during 24 through 26 September 2008.

were days with mainly little cloud cover, indicating high solar irradiance. The meteorological data show that during the first two events, the wind direction was northeast and in the early morning of 26 September changed to southwest. During these 3 days the wind speed gradually decreased, from $3.8 \mathrm{~m} / \mathrm{s}$ during the first event, to $2.3 \mathrm{~m} / \mathrm{s}$ during the second event and then to $0.8 \mathrm{~m} / \mathrm{s}$ during the third event. The size of the $\delta \mathrm{O}_{2} / \mathrm{N}_{2}$ signal is huge compared to other naturally occurring phenomena and the rate of change is fast. Although smaller in size, similar observations have been published by Lueker et al. (2003). In their observations at the coastal station Trinidad Head, these $\delta \mathrm{O}_{2} / \mathrm{N}_{2}$ decreases were caused by upwelling events. Similar events have been published by
Manning (2001). The observations in Baring Head are also hypothesized to be caused by upwelling events. As our observations at the F3 platform are significantly larger, we have studied the possibilities of artefacts or sources of contamination. Most of the effects can be ruled out immediately because of the lack of change in the concentration of $\mathrm{CO}_{2}$ (beyond our detection limit of $0.3 \mathrm{ppm}$ ). The only remaining possibilities were the use of liquid nitrogen on the platform or fractionation due to temperature variations at the air inlet (Blaine et al., 2006). The first possibility can be ruled out, as there are no cryogenics on the platform. The second effect might have some influence, but the size of the signal is larger than what could be expected for thermal fractionation at the air inlet or even leaks (R. F. Keeling, personal communication, 2009). Besides, if the events were caused by (thermal) fractionation they would be expected to occur more frequently. Also, the cloud cover record in this period does not fit the $\delta \mathrm{O}_{2} / \mathrm{N}_{2}$ signal, which makes thermal fractionation very unlikely. To be sure, the air-inlet has recently been shielded off from direct sunlight (but this has not lead to any noticeable difference yet, as the measurement period after the installation so far consists only of a few weeks of data). Excluding other possibilities, we therefore suggest that the observed $\mathrm{O}_{2}$ effects are very likely to be real and might indicate marine $\mathrm{O}_{2}$ uptake. This suggestion is supported by a possible correlation of the $\delta \mathrm{O}_{2} / \mathrm{N}_{2}$ signal with the daytime high tide at the platform, which suggests a correlation with marine phenomena. Also the change in the wave period (i.e. length of the waves) measured at the platform fits the $\delta \mathrm{O}_{2} / \mathrm{N}_{2}$ signal, showing a higher wave period during the events. However correlations with both tidal and wave period (which are correlated themselves) might be coincidental in this specific time period. For other events not shown here, 
the wave data are not available due to the change of ownership of the platform. Back trajectories, made with the Hysplit 4 lagrangian back trajectory model (Draxler and Rolph, 2003), of the second of the three events in Fig. 8 show that the air is originating from the east, and did not cross land at least $10 \mathrm{~h}$ before arriving at the platform. No changes are observed in the trajectories during the course of the event.

The dissolved $\mathrm{O}_{2}$ content in average North Sea water is about $9 \mathrm{~g} / \mathrm{m}^{3}$ (corresponding to $6.5 \mathrm{ml} / \mathrm{l}$ ) (Garcia et al., 2006). A rough estimate, based on a water column with a depth of $45 \mathrm{~m}$, and the assumption that the water column is taking up $\mathrm{O}_{2}$ from an air column of well-mixed air with a height of about $2 \mathrm{~km}$, gives the following result. In the hypothetical situation that all marine $\mathrm{O}_{2}$ is removed, this would then lead to a possible marine uptake corresponding to a decrease of around 3500 per meg from the atmosphere. The observed signal is about 10 times as small, thereby indicating a marine undersaturation of $10 \%$, so our observations correspond to a delivery of oxygen to the seawater of about $10 \%$ of the saturation value. Hence, it is possible that the seawater can take up the amount of $\mathrm{O}_{2}$ from the atmosphere, in which case the sea water must have been undersaturated by at least $10 \%$. However, such a large uptake would take a much longer time frame than what is shown in our observations. Manning has shown that for the event observed at Baring Head (Manning, 2001) an undersaturation of $2 \mathrm{ml} / \mathrm{l}$ would cause a drawdown of $\delta \mathrm{O}_{2} / \mathrm{N}_{2}$ of 80 per meg to take $18 \mathrm{~h}$ (A. C. Manning, personal communication, 2009). In our case however, the wind speed was much lower leading to an even slower marine $\mathrm{O}_{2}$ uptake process (Liss and Merlivat, 1986). Since in our case besides the lower wind speed, the size of the signal is even larger, the only plausible explanation for these observations - marine uptake - would take an unrealistic amount of time, leaving these observations without a good explanation.

Using the obtained $\mathrm{CO}_{2}$ and $\delta \mathrm{O}_{2} / \mathrm{N}_{2}$ values, the atmospheric potential oxygen (APO) can be obtained (Battle et al., 2006; Stephens et al., 1998). APO is defined by Eq. (7):

$\mathrm{APO}=\delta \mathrm{O}_{2} / \mathrm{N}_{2}+\frac{1.1 \cdot \Delta \mathrm{CO}_{2}}{\mathrm{~S}_{\mathrm{O}_{2}}} \quad$ (in per meg)

where $\mathrm{S}_{\mathrm{O}_{2}}$ and $\Delta \mathrm{CO}_{2}$ are defined as explained with Eq. (6). The $\Delta \mathrm{CO}_{2}$ value is multiplied by 1.1 , which is the global average stoichiometric ratio between $\mathrm{O}_{2}$ and $\mathrm{CO}_{2}$ in photosynthesis and respiration processes of the land biosphere (Severinghaus, 1995). This means that, - to a good approximation APO is unaffected by the activity of land biota and is therefore principally sensitive to ocean-atmosphere exchange of $\mathrm{O}_{2}$ and $\mathrm{CO}_{2}$ and only partly to fossil fuel combustion.

Figure 9 shows the atmospheric potential oxygen (APO) for both the continuous measurements and for the flask measurements. APO values for both independent measurement systems generally agree nicely. The data show a part of the seasonal cycle as expected during the period August through June. The peak-trough amplitude of the APO signal - about 75 per meg - is smaller than the $\delta \mathrm{O}_{2} / \mathrm{N}_{2}$ signal (about

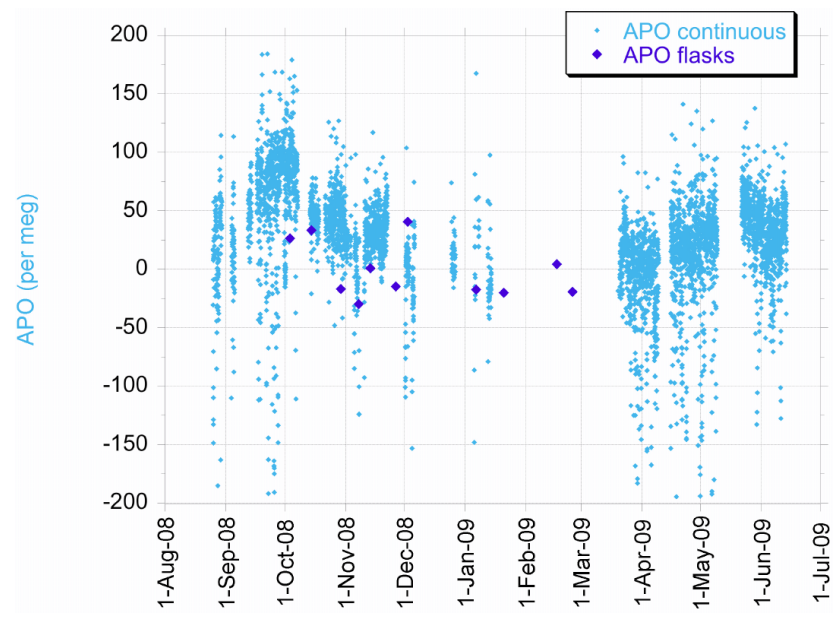

Fig. 9. Results of APO at the F3 platform for the period August 2008 through June 2009 showing the seasonal cycle as expected during this period. The results for the continuous measurement system (smaller diamonds) are shown together with the results of the flask samples (larger diamonds). The amplitude of the seasonal cycle of APO is around 75 permeg, and is composed of the oceanic APO seasonality and is also influenced by the fossil fuel combustion seasonality.

150 per meg), since the seasonality for land biota is removed from the signal (as explained with Eq. 7). The remaining part of the seasonality is the oceanic seasonality (in which we are interested), which is still influenced by the seasonal difference in fossil fuel combustion, both in amount and composition (Sirignano et al., 2008). A longer time series is required to make a more comprehensive analysis, including the trend and a correction for fossil fuel influences. This correction varies with the regional fossil fuel mix and might therefore be significant in a country such as the Netherlands with an unusually large natural gas share in the fossil fuel mix. Furthermore, this share of natural gas in the fossil fuel mix is much larger in winter than in summer.

\section{Conclusions and outlook}

\subsection{Improvements of the measurement system}

We have presented a new atmospheric measurement station in the North Sea, together with the initial results. Both continuous $\mathrm{CO}_{2}$ and $\delta \mathrm{O}_{2} / \mathrm{N}_{2}$ measurements and flask sampling will be continued during the coming years. The continuous $\delta \mathrm{O}_{2} / \mathrm{N}_{2}$ and $\mathrm{CO}_{2}$ measurement system will be improved during the coming period. As agreements during the start-up phase of this project between our institute and the oil company required the system to be installed in a short time frame, the initial testing phase was relatively short. With the system currently operational at the measurement site, improvements of the system will have a direct effect on the measurements. 
Several aspects leading to improvements in measurement precision and accuracy will be considered. First of all, our air inlet design might not be optimal. The possibilities of using an aspirated air inlet (Blaine et al., 2006) will be studied together with its benefits to the measurement precision. Further testing of the sample pump used in the system will be required in order to check for possible fractionation or leaks. The same applies for the Valco switching valves in the system. The Nafion pre-drier will be tested more extensively to see its possible influence on the $\delta \mathrm{O}_{2} / \mathrm{N}_{2}$ measurements. These tests will possibly enhance the measurement precision of the system, as this is very sensitive to leaks or fractionation. The pressure equalization in both lines of the system might be improved with a different pressure control setup (e.g. replacing the MKS sensors and valves). Replacing the (long-used) fuel cells with new ones could also improve the measurement precision. Furthermore the location of the Valco switching valve (which switches between fuel cells and CarboCaps every $5 \mathrm{~min}$ ) can be reconsidered. By placing the valve right before the Oxzilla inlets, the time required for stabilization of the signal might be decreased, enabling shorter switching cycles, i.e. more measurements per hour) or increasing the number of data points included in the calculation of the average, thereby possible increasing the measurement precision. Increasing the flows of the sample and reference gases will possibly also lead to improvements for the same reasons.

The calibration procedure of the system can possibly also be improved. Several aspects will be considered: firstly when switching from sample gas to calibration or target gas, the drying system has to be completely flushed which takes a considerable amount of time, in which no ambient measurements can be performed. The flushing time of the drying system could be decreased by minimizing the volume of the glass traps. Furthermore the setup could be altered in a way that the drying system is bypassed for the calibration and target gases, and using a separate smaller cryogenic trap for these gases. The measurement precision and accuracy can be enhanced by increasing the amount of calibration cylinders from 2 to 3 or more and increasing the cross-checking frequency of calibration cylinders in the CIO laboratory. With a higher amount of calibration cylinders, the possible influence of the non-linear response of the CarboCaps can be accounted for. Furthermore, the measurement frequency of the target cylinder could be increased, including one measurement to be performed independent of the calibration sequence. Finally, insulating the calibration and target cylinders in order to improve the temperature stability of reference, calibration and target cylinders will contribute to a better measurement precision and accuracy.

\subsection{Outlook}

By means of simultaneous $\mathrm{CO}_{2}$ and $\delta \mathrm{O}_{2} / \mathrm{N}_{2}$ measurements over longer time series (several years), information about the $\mathrm{CO}_{2}$ uptake by the North Sea region can be estimated. Future research will focus on data collection at the platform and comparison of the data to other European datasets. Our atmospheric measurements will be a valuable contribution to the marine studies that have been performed in the North Sea region. Recent studies show that the total North $\mathrm{Sea} \mathrm{CO}_{2}$ sink is declining over the past years (Thomas et al., 2007). During the summer period, there is a difference between the northern and the southern North Sea. The shallower part south of $54^{\circ} \mathrm{N}$ is a $\mathrm{CO}_{2}$ source, whereas the deeper part north of that boundary is a sink for $\mathrm{CO}_{2}$ (Bozec et al., 2005). The location of the platform at $54^{\circ} 51^{\prime} \mathrm{N}, 4^{\circ} 44^{\prime} \mathrm{E}$ is therefore ideal in order to compare atmospheric data with the data from marine measurements from North Sea cruises. The atmospheric measurements at the F3 platform can possibly be extended with on-site marine measurements. Additional data can be obtained by measurements of the partial pressure of $\mathrm{CO}_{2}$ $\left(p \mathrm{CO}_{2}\right)$ and $\mathrm{O}_{2}$ in the seawater surrounding the platform. The results will be used in model studies, which will reveal more details about regional and global $\mathrm{CO}_{2}$ uptake by coastal seas and the world's oceans.

Acknowledgements. This research is supported by the European Integrated Project CARBOOCEAN contract number 511176 (GOCE). The authors would like to thank F3, NAM, Shell and GdF Suez staff members for their support to this project. We are especially grateful for the generous ongoing logistic and technical support by NAM and GdF Suez. Furthermore the authors thank CIO staff members B. A. M. Kers, J. K. Schut and H. G. Jansen for their contributions. The authors additionally thank R. L. Thompson for her recommendations and support in the start-up phase of the project. The authors also would like to express their gratitude to the anonymous referee and A. Manning for their valuable comments, which have improved this text considerably.

Edited by: D. Toohey

\section{References}

Battle, M., Mikaloff Fletcher, S. E., Bender, M. L., Keeling, R. F., Manning, A. C., Gruber, N., Tans, P. P., Hendricks, M. B., Ho, D. T., Simonds, C., Mika, R., and Paplawsky, B.: Atmospheric potential oxygen: New observations and their implications for some atmospheric and oceanic models, Global Biogeochem. Cy., 20, GB1010, doi:10.1029/2005GB002534, 2006.

Bender, M. L., Ellis, T., Tans, P., Francey, R., and Lowe, D.: Variability in the $\mathrm{O}_{2} / \mathrm{N}_{2}$ ratio of southern hemisphere air, 1991-1994: Implications for the carbon cycle, Global Biogeochem. Cy., 10, 9-21, 1996.

Bender, M. L., Ho, D. T., Hendricks, M. B., Mika, R., Battle, M. O., Tans, P. P., Conway, T. J., Sturtevant, B., and Cassar, N.: Atmospheric $\mathrm{O}_{2} / \mathrm{N}_{2}$ changes, 1993-2002: Implications for the par- 
titioning of fossil fuel $\mathrm{CO} 2$ sequestration, Global Biogeochem. Cy., 19, GB4017, doi:10.1029/2004GB002410, 2005.

Bender, M. L., Tans, P. P., Ellis, J. T., Orchardo, J., and Habfast, K.: A High-Precision Isotope Ratio Mass-Spectrometry Method for Measuring the $\mathrm{O}_{2} / \mathrm{N}_{2}$ Ratio of Air, Geochim. Cosmochim. Ac., 58, 4751-4758, 1994.

Blaine, T. W., Keeling, R. F., and Paplawsky, W. J.: An improved inlet for precisely measuring the atmospheric $\mathrm{Ar} / \mathrm{N}_{2}$ ratio, Atmos. Chem. Phys., 6, 1181-1184, 2006,

http://www.atmos-chem-phys.net/6/1181/2006/.

Bozec, Y., Thomas, H., Elkalay, K., and de Baar, H. J. W.: The continental shelf pump for $\mathrm{CO}_{2}$ in the North Sea - evidence from summer observation, Mar. Chem., 93, 131-147, doi:10.1016/j.marchem.2004.07.006, 2005.

BP: The world's largest Gem: BP's new LNG carrier British Emerald, BP Frontiers, Sunbury on Thames, UK, 2007.

Draxler, R. R. and Rolph, G. D.: HYSPLIT (HYbrid Single-Particle Lagrangian Integrated Trajectory). Model access via NOAA ARL READY Website (http://www.arl.noaa.gov/ready/hysplit4. html, last access: 22 January 2010), NOAA Air Resources Laboratory, Silver Spring, MD., 2003.

Forster, P., Ramaswamy, V., Artaxo, P., Berntsen, T., Betts, R., Fahey, D. W., Haywood, J., Lean, J., Lowe, D. C., Myhre, G., Nganga, J., Prinn, R., Raga, G., Schulz, M., and Van Dorland, R.: Changes in Atmospheric Constituents and in Radiative Forcing, in: Climate Change 2007: The Physical Science Basis. Contribution of Working Group I to the Fourth Assessment Report of the Intergovernmental Panel on Climate Change, edited by: Solomon, S., Qin, D., Manning, M., Chen, Z., Marquis, M., Averyt, K. B., Tignor, M., and Miller, H. L., Cambridge University Press, Cambridge, United Kingdom and New York, NY, USA, 129-234, 2007.

Gamnitzer, U., Karstens, U., Kromer, B., Neubert, R. E. M., Meijer, H. A. J., Schroeder, H., and Levin, I.: Carbon monoxide: a quantitative tracer for fossil fuel $\mathrm{CO}_{2}$ ?, J. Geophys. Res.-Atmos., 111, 1-19, doi:10.1029/2005jd006966, 2006.

Garcia, H. E., Locarnini, R. A., Boyer, T. P., and Antonov, J. I.: World Ocean Atlas 2005, Vol. 3: Dissolved Oxygen, Apparent Oxygen Utilization, and Oxygen Saturation, NOAA Atlas NESDIS 63 Edn., edited by: Levitus, S., US Government Printing Office, Washington, DC, 342 pp., 2006.

GLOBALVIEW-CO2: Cooperative Atmospheric Data Integration Project - Carbon Dioxide, CD-ROM, NOAA ESRL, Boulder, Colorado, 2008.

Keeling, R. F.: Development of an Interferometric Oxygen Analyzer for Precise Measurement of the Atmospheric $\mathrm{O}_{2}$ Mole Fraction, Division of Applied Sciences, Harvard University, Cambridge, Massachusetts, 178 pp., 1988a.

Keeling, R. F.: Measuring Correlations between Atmospheric Oxygen and Carbon-Dioxide Mole Fractions - a PreliminaryStudy in Urban Air, J. Atmos. Chem., 7, 153-176, doi:10.1007/BF00048044, 1988b.

Keeling, R. F., Manning, A. C., Paplawsky, W. J., and Cox, A. C.: On the long-term stability of reference gases for atmospheric $\mathrm{O}_{2} / \mathrm{N}_{2}$ and $\mathrm{CO}_{2}$ measurements, Tellus $\mathrm{B}, 59,3-14$, doi:10.1111/j.1600-0889.2006.00228.x, 2007.

Keeling, R. F., Najjar, R. P., Bender, M. L., and Tans, P. P.: What Atmospheric Oxygen Measurements Can Tell Us About the Global Carbon-Cycle, Global Biogeochem. Cy., 7, 37-67, 1993.
Keeling, R. F., Piper, S. C., and Heimann, M.: Global and hemispheric $\mathrm{CO}_{2}$ sinks deduced from changes in atmospheric $\mathrm{O}_{2}$ concentration, Nature, 381, 218-221, doi:10.1038/381218a0, 1996.

Keeling, R. F. and Shertz, S. R.: Seasonal and Interannual Variations in Atmospheric Oxygen and Implications for the Global Carbon-Cycle, Nature, 358, 723-727, doi:10.1038/358723a0, 1992.

Kozlova, E. A., Manning, A. C., Kisilyakhov, Y., Seifert, T., and Heimann, M.: Seasonal, synoptic, and diurnal-scale variability of biogeochemical trace gases and $\mathrm{O}_{2}$ from a 300-m tall tower in central Siberia, Global Biogeochem. Cy., 22, GB4020, doi:10.1029/2008GB003209, 2008.

Langenfelds, R. L., Francey, R. J., Steele, L. P., Battle, M., Keeling, R. F., and Budd, W. F.: Partitioning of the global fossil $\mathrm{CO}_{2}$ sink using a 19-year trend in atmospheric $\mathrm{O}_{2}$, Geophys. Res. Lett. 26, 1897-1900, 1999.

Liss, P. and Merlivat, L.: Air-sea gas exchange rates: Introduction and synthesis, in: The role of sea-air exchange in geochemical cycling, edited by: Menard, P., Reidel, Dordrecht, 113-127, 1986.

Lueker, T. J., Walker, S. J., Vollmer, M. K., Keeling, R. F., Nevison, C. D., Weiss, R. F., and Garcia, H. E.: Coastal upwelling air-sea fluxes revealed in atmospheric observations of $\mathrm{O}_{2} / \mathrm{N}_{2}, \mathrm{CO}_{2}$ and $\mathrm{N}_{2} \mathrm{O}$, Geophys. Res. Lett., 30, 1292, doi:10.1029/2002GL016615, 2003.

Machta, L. and Hughes, E.: Atmospheric Oxygen in 1967 to 1970, Science, 168, 1582-1584, doi:10.1126/science.168.3939.1582, 1970.

Mak, J. E. and Brenninkmeijer, C. A. M.: Compressed-Air Sample Technology for Isotopic Analysis of Atmospheric Carbon-Monoxide, J. Atmos. Ocean. Technol., 11, 425-431, doi:10.1175/1520-0426(1994)011, 1994.

Manning, A. C.: Temporal variability of atmospheric oxygen from both continuous measurements and a flask sampling network: Tools for studying the global carbon cycle, Ph.D. thesis, Scripps Institution of Oceanography, La Jolla, California, USA, University of California, San Diego, 202 pp., 2001.

Manning, A. C. and Keeling, R. F.: Global oceanic and land biotic carbon sinks from the Scripps atmospheric oxygen flask sampling network, Tellus B, 58, 95-116, doi:10.1111/j.16000889.2006.00175.x, 2006.

Manning, A. C., Keeling, R. F., and Severinghaus, J. P.: Precise atmospheric oxygen measurements with a paramagnetic oxygen analyzer, Global Biogeochem. Cy., 13, 1107-1115, doi:10.1029/1999GB900054, 1999.

Neubert, R. E. M., Spijkervet, L. L., Schut, J. K., Been, H. A., and Meijer, H. A. J.: A computer-controlled continuous air drying and flask sampling system, J. Atmos. Ocean. Technol., 21, 651659, doi:10.1175/1520-0426(2004)021, 2004.

Patecki, M. and Manning, A. C.: First results from shipboard atmospheric $\mathrm{O}_{2}$ and $\mathrm{CO}_{2}$ measurements over the North Atlantic Ocean, OCEANS 2007 - Europe, Aberdeen, UK, 1821 June 2007, 2007.

Popa, M. E., Gloor, M., Manning, A. C., Jordan, A., Schultz, U., Haensel, F., Seifert, T., and Heimann, M.: Measurements of greenhouse gases and related tracers at Bialystok tall tower station in Poland, Atmos. Meas. Tech. Discuss., 2, 2587-2637, 2009 ,

http://www.atmos-meas-tech-discuss.net/2/2587/2009/. 
Severinghaus, J. P.: Studies of the terrestrial O2 and carbon cycles in sand dune gases and in Biosphere 2, Ph.D. Thesis, Columbia University, New York, USA, 1995.

Sirignano, C., Neubert, R. E. M., Meijer, H. A. J., and Rödenbeck, C.: Atmospheric oxygen and carbon dioxide observations from two European coastal stations 2000-2005: continental influence, trend changes and APO climatology, Atmos. Chem. Phys. Discuss., 8, 20113-20154, 2008,

http://www.atmos-chem-phys-discuss.net/8/20113/2008/.

Stephens, B. B.: Field-based Atmospheric Oxygen Measurements and the Ocean Carbon Cycle, Ph.D. thesis, Scripps Institution of Oceanography, University of California, San Diego, 222 pp., 1999.

Stephens, B. B., Bakwin, P. S., Tans, P. P., Teclaw, R. M., and Baumann, D. D.: Application of a differential fuel-cell analyzer for measuring atmospheric oxygen variations, J. Atmos. Ocean. Tech., 24, 82-94, doi:10.1175/JTECH1959.1, 2007.

Stephens, B. B., Keeling, R. F., Heimann, M., Six, K. D., Murnane, R., and Caldeira, K.: Testing global ocean carbon cycle models using measurements of atmospheric $\mathrm{O}_{2}$ and $\mathrm{CO}_{2}$ concentration, Global Biogeochem. Cy., 12, 213-230, 1998.

Thomas, H., Prowe, A. E. F., van Heuven, S., Bozec, Y., de Baar, H. J. W., Schiettecatte, L. S., Suykens, K., Kone, M., Borges, A. V., Lima, I. D., and Doney, S. C.: Rapid decline of the $\mathrm{CO}_{2}$ buffering capacity in the North Sea and implications for the North Atlantic Ocean, Global Biogeochem. Cy., 21, GB4001, doi:10.1029/2006GB002825, 2007.

Thompson, R. L., Manning, A. C., Gloor, E., Schultz, U., Seifert, T., Hänsel, F., Jordan, A., and Heimann, M.: In-situ measurements of oxygen, carbon monoxide and greenhouse gases from Ochsenkopf tall tower in Germany, Atmos. Meas. Tech., 2, 573591, 2009, http://www.atmos-meas-tech.net/2/573/2009/.

Thompson, R. L., Manning, A. C., Lowe, D. C., and Weatherburn, D. C.: A ship-based methodology for high precision atmospheric oxygen measurements and its application in the Southern Ocean region, Tellus B, 59, 643-653, doi:10.1111/j.16000889.2007.00292.x, 2007.
Tohjima, Y.: Method for measuring changes in the atmospheric $\mathrm{O}_{2} / \mathrm{N}_{2}$ ratio by a gas chromatograph equipped with a thermal conductivity detector, J. Geophys. Res.-Atmos., 105, 1457514584, 2000 .

Tohjima, Y., Machida, T., Watai, T., Akama, I., Amari, T., and Moriwaki, Y.: Preparation of gravimetric standards for measurements of atmospheric oxygen and reevaluation of atmospheric oxygen concentration, J. Geophys. Res., 110, D11302, doi:10.1029/2004JD005595, 2005.

Tohjima, Y., Mukai, H., Nojiri, Y., Yamagishi, H., and Machida, T.: Atmospheric $\mathrm{O}_{2} / \mathrm{N}_{2}$ measurements at two Japanese sites: estimation of global oceanic and land biotic carbon sinks and analysis of the variations in atmospheric potential oxygen (APO), Tellus B, 60, 213-225, doi:10.1111/j.1600-0889.2007.00334.x, 2008.

Valentino, F. L., Leuenberger, M., Uglietti, C., and Sturm, P.: Measurements and trend analysis of $\mathrm{O}_{2}, \mathrm{CO}_{2}$ and $\delta^{13} \mathrm{C}$ of $\mathrm{CO}_{2}$ from the high altitude research station Jungfraujoch, Switzerland - A comparison with the observations from the remote site Puy de Dome, France, Sci. Total Environ., 391, 203-210, doi:10.1016/j.scitotenv.2007.10.009, 2008.

van der Laan, S., Neubert, R. E. M., and Meijer, H. A. J.: A single gas chromatograph for accurate atmospheric mixing ratio measurements of $\mathrm{CO}_{2}, \mathrm{CH}_{4}, \mathrm{~N}_{2} \mathrm{O}, \mathrm{SF}_{6}$ and $\mathrm{CO}$, Atmos. Meas. Tech., 2, 549-559, 2009, http://www.atmos-meas-tech.net/2/549/2009/.

van der Plicht, J., Wijma, S., Aerts, A. T., Pertuisot, M. H., and Meijer, H. A. J.: Status report: The Groningen AMS facility, Nucl. Instrum. Meth. B, 172, 58-65, doi:10.1016/S0168583X(00)00284-6, 2000.

WMO: Report of the 14th WMO/IAEA Meeting of Experts on Carbon Dioxide Concentration and Related Tracers Measurement Techniques, Helsinki, Finland, 10-13 September 2007, World Meteorological Organization, Geneva, Switzerland, 2009. 